\title{
Job involvement in Iranian Custom Affairs Organization: the Role of Organizational Justice and Job Characteristics
}

\author{
Freyedon Ahmadi \\ Public management Department, Payame Noor university, 19395-3697 Tehran, I.R. of IRAN
}

Accepted: December 7, 2011 Published: January 9, 2012

doi:10.5296/ijhrs.v2i1.1249 URL: http://dx.doi.org/10.5296/ijhrs.v2i1.1249

\begin{abstract}
Job Involvement (JI) is defined as employee's psychological identification with current job. Some researchers argue that $\mathrm{JI}$ is explained only by intrinsic variables. In contrast, others use organizational variables as drivers of JI. The purpose of Current research is to explain JI using simultaneously two important but ignored organizational drivers, as organizational justice (OJ) and job characteristics (JC). OJ is conceptualized by three dimensions as distributive, procedural, and interactional justice. Also, JC model is divided, as Henchman and Oldham (1976) suggested, into five dimensions as task variety, task identity, task significance, job autonomy, and feedback. The question is: do OJ and JC dimensions can explain and predict variance of JI?

By selecting systematically random 140 employees from Iranian custom affairs organization (ICAO), standard questionnaire is sent in order to fill it based on self-report. Structural equation modeling approach results show that distributive and procedural justices, task variety task identity, autonomy, and feedback have significantly positive impacts on JI, but interactional justice and task significance do not. Some practical and theoretical suggestions and recommendations are presented at the end of report.
\end{abstract}

Key words: job involvement, organizational justice, job characteristics, ICAO.

\section{Introduction and Research Literature}

Job involvement is a principal factor in the lives of most people; employees in the workplace are mentally and emotionally influenced by their degree of involvement in work. Job involvement indicates the degree to which the workplace contributes to one's self image (Lodahl \& Kejner, 1965) and satisfies important needs (Dubin, 1956; 1968). We expect that job involvement will be primarily shaped by individual attributes and previous life experiences rather than by workable levers. 
Hackman and Oldham (1975) proposed five "core" dimensions for evaluating the immediate work environment constituting the Job Diagnostic Survey JDS. These core dimensions turned out to be associated significantly with job satisfaction and a high sense of workers' motivation. That is, the work environment source consisted of five dimensions, namely those of skill variety, task identity; ask significance, autonomy and feedback.

Hackman and Oldham's model proposes that attention to five job design characteristics (skill variety, task identity, task significance, autonomy and feedback) produce three critical psychological states (experienced meaningfulness of the work, experienced responsibility for outcomes of the work, and knowledge of the actual results of the work activities) which increase the likelihood of positive personal and work outcomes, especially from employees with a high growth-need strength, including: high internal work motivation, high quality performance, high satisfaction with the work, and low absenteeism and turnover.

The most important characteristic that receives huge attention in Hackman and Oldham's study is the meaningfulness of the work that means to what extent the individual perceives the work as significant and important. Job meaningfulness can be defined as the product of three dimensions: skill variety (activities that challenge skills and abilities); task identity (the extent to which the job requires completion of a "whole", identifiable peace of work); task significance (how substantially the job has impacts on other people's lives.

Feedback to staff, the final characteristic of Hackman and Oldham's Job Characteristics Model, has been greatly improved at many hospitality institutions but is often lacking in many of the smaller food service only organizations like clubs and restaurants. The value of this characteristic should not be discarded as simple steps like weekly, monthly and yearly sales; covers, earnings results summaries have great universal employee appeal. Another simple feedback tool is the establishment of an annual award to the employee or unit of the year. In addition, letters received from customers can be copied and circulated to the team responsible for service delivery.

\section{Organizational justice as mediator of job involvement}

Greenberg (1990a) reported that early social justice theories on organizations were derived to test principles of justice in general social interactions, not organizations in particular. Thus, these theories have experienced partial success when used to explain various forms of organizational behaviors. Recently, conceptual models have been developed that include variables and issues directly relevant to organizational functioning. With these models, researchers have conducted research to explain and describe the role of fairness in the workplace (Greenberg, 1987b).

Judgments about fairness are made by means of a fairly simple process. Sheppard, Lewicki, and Minton (1992) present two principles to judge the justice of a decision, procedure, or action. The first principle of justice requires a judgment of balance. The principle requires one to compare a given decision against other similar decisions in similar situations. Comparisons of balance are made by evaluating the outcomes of two or more people and equating those outcomes to the value of the inputs they provide to the organization. Correctness is the second internal principle by which a decision, procedure, or action is 
evaluated. Correctness can be seen as the quality which makes the decision seem right. Therefore, one makes decisions about the perceived justice of some action that harms or benefits someone by deciding whether the action appears to be both balanced and correct.

In general, research about organizational justice has focused on two major issues: employees' responses to the outcomes they receive, and the means by which they obtain these outcomes, that is, the procedures used (Cropanzano \& Greenberg, 1997). In other words, theorists in the field of organizational justice have distinguished between conceptualizations of justice that deal with the content of fairness, or what the decisions are, which is termed distributive justice, and those that focus on the process of fairness, or how decisions are made, called procedural justice (Greenberg, 1990a). A great deal of research concerning justice has historically emphasized the distribution of payment and other work-related rewards derived from equity theory (Greenberg, 1987b). Although this outcome-oriented perspective explains how employees react to the nature, level, and distribution of organizational rewards, it ignores the procedures or means through which ends are established. Therefore, the research focus has recently shifted from distributive justice to procedural justice (Greenberg, 1990a). Indeed, rather than simply being a means used to achieve distributive justice, procedural justice has value in its own right. In other words, the procedures used to determine a particular outcome can be more important than an actual outcome itself (Folger \& Greenberg, 1985; Folger \& Martin, 1986; Martin \& Bennett, 1996; Martin \& Nagao, 1989).

Given that the distinction between distributive justice and procedural justice has been empirically established, there was a need to consider how these varieties of justice relate to various organizational variables (Greenberg, 1990a). A number of empirical studies have been conducted to investigate the predictive roles of distributive justice and procedural justice on organizational outcomes. Overall, the results of these studies suggest that distributive justice and procedural justice may be predictive of different attitudes (Greenberg, 1990a). In general, distributive justice may be a more important predictor of personal outcomes such as pay satisfaction (McFarlin \& Sweeney, 1992), whereas procedural justice may have strong effects on attitudes about institutions or authorities such as organizational commitment and trust in management (Folger \& Konovsky, 1989; Lind \& Tyler, 1988; McFarlin \& Sweeney, 1992). Although individuals' reactions may differ depending on the extent to which they focus on outcomes or procedures, both procedural justice and distributive justice contribute to individuals' perceptions of organizational fairness (Schminke, Ambrose, \& Noel, 1997).

Based was said about job involvement and organizational justice as well as task attributes, research hypothesis were defined below:

H1: Distribute justice has impact on job involvement.

$\mathrm{H} 2$ : procedure justice has impact on job involvement.

H3: interpersonal justice has impact on job involvement.

H4: skill variety has impact on job involvement.

H5: task identity has impact on job involvement.

H6: task significance has impact on job involvement.

H7: task autonomy has impact on job involvement.

H8: task feedback has impact on job involvement. 


\section{Methodology:}

In current study is used of applied research and descriptive branch as well as casual as research method. 140 people of custom affairs organization were selected as sample. For gathering data is used of questionnaire tools. Therefore to test of job involvement is used of Kanungo, for organizational justice Niehoff\& Moorman and for job attribute Hackman \& Oldham questionnaire.

\section{Finding:}

Analysis is a confirmation factor for role of organizational justice and task attributes to create proper job involvement. After discussing how to calculate the results of elements, and before entering in to the stage of hypotheses tests, we should recognize correctness of the role of independent and dependent variables in the model. this task will be done by structural equation models.

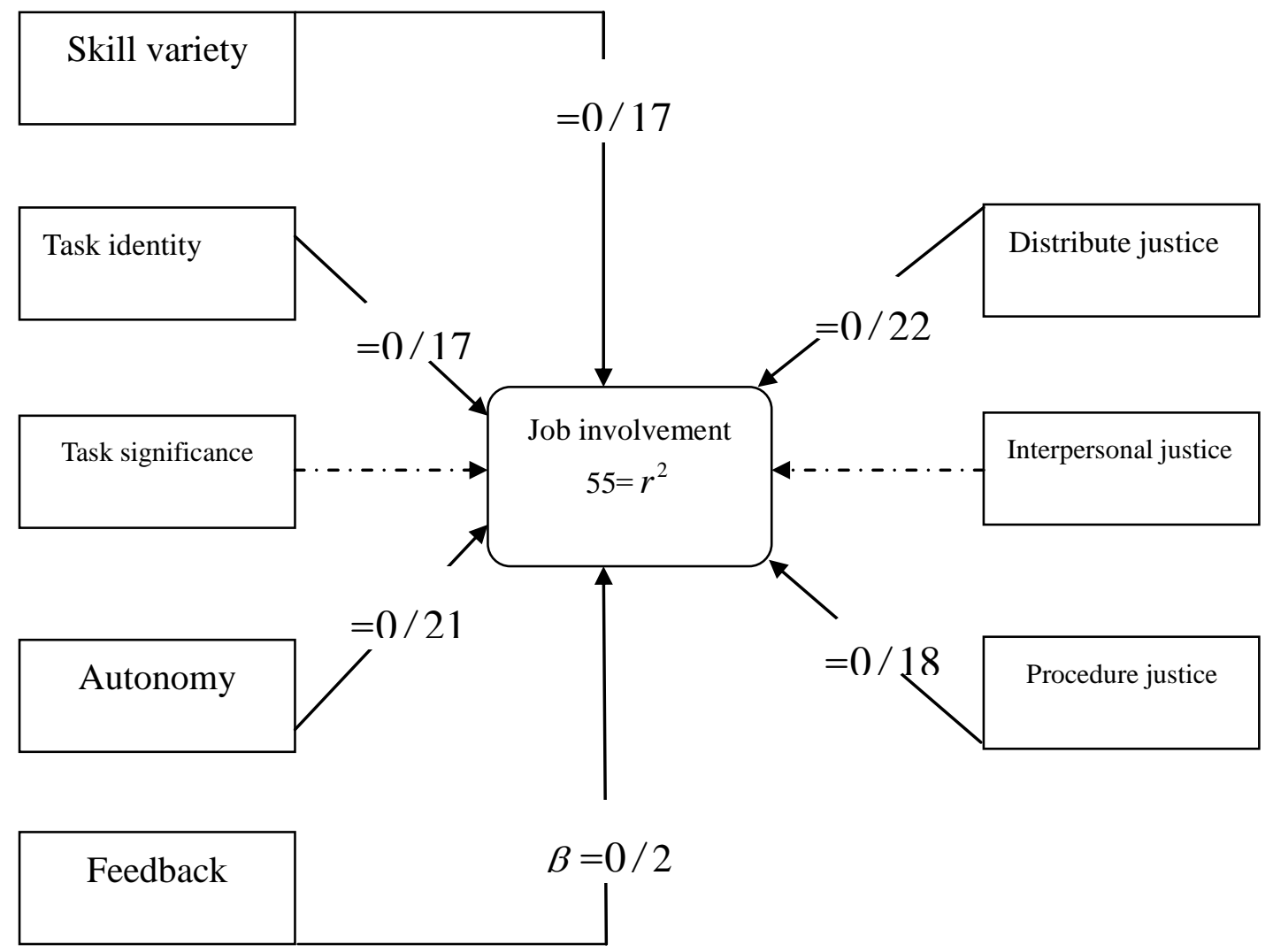

Figure 1: structural model diagram

The results of first hypothesis indicted that distribute justice and job involvement have positive and meaningful correlation together. Standard beta for this correlation is 0.22 and its p-value is 2.71 . So with 95 percent certainty we could say perception of justice in distribute reward in organization has positive impact on their job involvement. So the first hypothesis is accepted. 
The results of second hypothesis indicted that procedure justice and job involvement has positive and meaningful correlation together. Standard beta for this correlation is 0.18 and its p-value is 2.08 . So with 95 percent certainty we could say perception of justice in distribute task and process in organization has positive impact on their job involvement. So the second hypothesis is accepted.

In third hypothesis beta standard for correlation between interpersonal justice and job involvement is 0.11 . But its p- value is 1.36 and because of this amount under 1.96 , so the third hypnosis not accepted.

In fourth hypothesis beta standard for correlation between Varity skills and job involvement is 0.17 . Its p- value is 2.09 and because of this amount up of 1.96, so the fourth hypnosis is accepted. Therefore if skill of task were variety, its job involvement was increase.

About the other hypotheses we could say task identity, autonomy and feed back in organization have positive impact on job involvement, but task significant did not has positive effect on job involvement.

\section{Conclusion:}

The main purpose of this paper was identifies factors that they have positive and meaningful correlation with job involvement. For achievement of this aim were selected 140 people of custom affairs organization in Iran. Task attributes and organizational justice was defined as two main factors that they have important effect on job involvement. The results of this paper were indicted that distribute and procedure justice in organization and all dimension of task attribute except task significant have positive impact on job involvement.

\section{Reference:}

1. Cropanzano, R., \& Greenberg, J. (1997). Progress in organizational justice: Tunneling through the maze. In C. L. Cooper., \& I. T. Robertson (Eds.), International Review of Industrial and Organizational Psychology, 12, 317-372. Chichester: John Wiley \& Sons.

2. Distributive and procedural justice effects. Journal of Experimental Social Psychology, 22,(6), 531-546.

3. Dubin, R. (1956), "Industrial workers' world: a study of the 'central life interests' of industrial workers", Social Problems, Vol. 3, pp. 131-42.

4. Folger, R., \& Greenberg, J. (1985). Procedural justice: An interpretive analysis of personnel systems. In K. M. Rowland \& G.R. Ferris (Eds.), Research in Personnel and Human Resources Management, 3, 141-183.

5. Folger, R., \& Martin, C. L. (1986). Relative deprivation and referent cognitions:

6. Greenberg, J. (1987b). A taxonomy of organizational justice theories. Academy ofManagement Review, 12,(1), 9-22. 
7. Greenberg, J. (1990b). Employee theft as a reaction to underpayment inequity: Thehidden cost of pay cuts. Journal of Applied Psychology, 75,(5), 561-568.

8. Hackman, J. R., \& Oldham, G. R. (1976). Motivation through the design of work: Test of a theory. Organizational Behavior and Human Performance, 16, 250-279.

9. Hackman, J. R., \& Oldham, G. R. (1980). Work redesign. Reading, MA: Addison-Wesley.

10. Lodhal, T.M. and Kejner, M.M. (1965), "The definition and measurement of job involvement", Journal of Applied Psychology, Vol. 49, pp. 24-33.

11. Martin, C. L., \& Bennett, N. (1996). The role of justice judgments in explaining the relationship between job satisfaction and organizational commitment. Group \& Organizational Management, 21,(1), 84-104.

12. Martin, C. L., \& Nagao, D. (1989). Some behavioral consequences of computerized interviewing. Journal of Applied Psychology, 74,(1), 72-80.

13. McFarlin, D. B., \& Sweeney, P. D. (1992). Distributive and procedural justice aspredictors of satisfaction with personal and organizational outcomes. Academy of Management Journal, 35,(3), 626-637.

14. Schminke, M., Ambrose, M. L., \& Noel, T. W. (1997). The effect of ethical frameworks on perceptions of organizational justice. Academy of Management Journal, 40,(5), 1190-1207. 